\title{
Pencegahan Kesalahan Alarm Dalam Sistem Pendeteksi Dini Kebakaran dan Pemadaman Berbasis Internet of Things
}

\author{
Mumuh Muharam, Melda Latif, Baharuddin, Ibnum Richaflor \\ Jurusan Teknik Elektro, Fakultas Teknik, Universitas Andalas, Kampus Limau Manis, Padang, 25163, Indonesia
}

\section{ARTICLE INFORMATION}

Received: November $15^{\text {th }}, 2019$

Revised: June $24^{\text {th }}, 2020$

Available online: September $30^{\text {th }}, 2020$

\section{KEYWORDS}

False Alarm, Early Fire Detection, Internet of

Things

\section{CORRESPONDENCE}

Phone: +6281378222469

E-mail: mumuh@eng.unand.ac.id

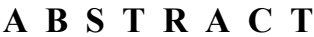

False alarm in fire detection can cause a huge loss. False alarm is generated by unwanted signal of smoke detector such as outdoor smoke or smoking. Therefore, it is designed a system that can reduce false alarm. The purposed system is built based on three components, those are sensors, actuators and data communication. Sensors are smoke, flame and camera sensor. Smoke sensor is used as the first thing to sense a signal from the system that warns the system there is a fire. Flame sensor and camera are used to confirm that a signal of fire whether false alarm or not. Internet of Things (IoT) is applied to control the system. The result show that the system is applicable.

\section{PENDAHULUAN}

Kebakaran merupakan bencana yang sangat merugikan bagi kehidupan manusia dimana manusia dapat kehilangan harta benda ataupun nyawa. Oleh karena itu semua orang baik secara lembaga ataupun individu berusaha menemukan solusi untuk mengatasi bencana kebakaran ini [1] [2]. Salah satu solusi yang ditawarkan dan menjadi standar adalah penggunaan detektor asap untuk deteksi dini kebakaran pada setiap gedung [3]. Akan tetapi ternyata pendeteksian kebakaran menggunakan detektor asap memberikan alarm yang salah (false alarm) sebagai contoh di Inggris dalam periode 2011-2012 dari 584500 alarm kebakaran ternyata 53,4\% adalah false alarm [4], sedangkan di Amerika Serikat dalam tahun 2012 terdapat lebih dua juta false alarm [5]. Alarm yang salah ini menyebabkan kerugian materi yang sangat besar [4] [5].

Sistem pendeteksi dini kebakaran memiliki komponen detektor asap dan alarm yang terintegrasi dengan sistem Badan Pemadam Kebakaran. False alarm adalah sinyal alarm kebakaran yang menyebabkan sistem pendeteksi kebakaran dan alarm menyala walaupun tidak ada kondisi kebakaran [6]. Salah alarm (false alarm) dapat terjadi dalam setiap kejadian alarm kebakaran. Terdapat beberapa penyebab false alarm. Pertama, adanya https://doi.org/10.25077/jitce.4.02.53-62.2020 kesalahan manusia yang memalsukan panggilan ke Badan pemadam kebakaran [4] [5] [6]. Bahkan di sekitar tahun 1970-an hal ini menjadi fenomena yang sangat luas di Amerika Serikat [5], tetapi dengan seiringnya waktu adanya kesadaran bahwa pentingnya alarm kebakaran tersebut untuk disikapi. Kedua, adanya kerusakan dari sistem pendeteksi [4] [5] [6]. Ketiga, adanya fenomena pembakaran atau pengaruh lingkungan seperti asap dari pembakaran lingkungan sekitar bangunan [4] [5] [6].

Penelitian sebelumnya menambahkan beberapa jenis sensor untuk memastikan adanya api setelah asap terdeteksi seperti penelitian [7] yang menentukan lokasi api. Penelitian [8] menggunakan aplikasi berbasis video untuk menentukan klasifikasi sinyal kebakaran yang diberikan sensor asap. Kedua penelitian ini belum memberikan adanya sistem pemberitahuan secara otomatik adanya kebakaran. Padahal, pemberitahuan atau alarm adanya kebakaran sejak dini menjadi salah satu pencegahan kebakaran.

Oleh karena itu, perlu dilakukan penelitian yang dapat memastikan adanya sumber api setelah sensor asap mendeteksi adanya asap dan juga pemberitahuan atau alarm secara otomatis. Pertama, dibangun sistem pendeteksian dini adanya asap. Kedua, perlunya sensor api yang dapat menentukan lokasi titik api. Ketiga, diperlukannya sebuah sensor yang dapat memastikan

Attribution-NonCommercial 4.0 International. Some rights reserved 
bahwa api yang terdeteksi adalah betul api yang membahayakan. Salah satu sensor yang dapat melakukan hal tersebut adalah sensor kamera. Terakhir, perlu dibangun sebuah sistem pemberitahuan kebakaran dini yang dapat menjangkau wilayah yang luas atau suatu komunitas. Hal ini dapat dilakukan menggunakan teknologi internet. Penelitian [9] dan [10] memanfaatkan teknologi Internet of Things dalam sistem pemberitahuan dini kebakaran.

Penelitian ini bertujuan untuk membangun sebuah purwarupa sistem pendeteksi dini dan pemadam kebakaran otomatis berbasiskan internet of things. Terdapat dua bagian pemprosesan data. Bagian pertama, sistem akuisisi data dari sensor maupun perintah ke aktuator menggunakan mikrokontroler Arduino Mega. Sensor yang digunakan adalah sensor asap MQ-2, dua buah sensor api, sensor kamera, sedangkan aktuator yang digunakan adalah motor servo sebagai penggerak sensor api dan pompa air untuk pemadam apinya. Bagian kedua adalah komunikasi data menggunakan IoT dengan komponen Ethernet shield, pc server dan HP android. Purwarupa ini dibuat dengan harapan dapat mencegah adanya false alarm dan dapat mendeteksi dini kebakaran juga memamadamkan kebakaran. Hal ini diharapkan dapat mengurangi kerugian akibat kebakaran.

Dalam makalah ini, skenario pencegahan kesalahan alarm adalah berdasarkan jenis penyebab kedua dan ketiga. Untuk penyebab jenis kedua, sensor asap aktif dan akan mengaktifkan sensor api akan tetapi bila sensor api tidak menemukan adanya api maka sistem akan memperingati 'tidak bahaya'. Sedangkan untuk penyebab jenis ketiga dengan adanya asap, sistem akan mengaktifkan sensor api. Bila terdapat api menurut sensor api, maka sistem akan mengaktifkan kamera yang akan mengambil foto dari sumber api.

\section{Pengertian Kebakaran dan Penanganannya}

Kebakaran merupakan sebuah bencana yang disebabkan oleh api atau pembakaran tidak terkendali, dapat membahayakan kehidupan manusia dan lingkungannya. Kebakaran bisa jadi disengaja ataupun tidak disengaja. Kebakaran merupakan sebuah fenomena yang disebabkan karena adanya ancaman potensial sejak tanda tanda api muncul hingga penjalaran api, asap dan gas yang muncul [11]. Sangat banyak penyebab dari kebakaran. Oleh karena itu kebakaran dapat terjadi di mana saja, seperti di hutan, di tempat kerja, di perumahan, dan di tempat lainnya.

Kebakaran seharusnya dapat ditanggulangi secara dini, yaitu dengan mendeteksi munculnya asap [12] dan titik api [7]. Lebih jauh, pendeteksian dini untuk asap sangat penting bahkan hal ini menjadi standar pembangunan gedung-gedung [3].

Pemadaman kebakaran secara otomatis dapat dikelompokan dalam dua jenis, yaitu penyemprot air statis dan dinamis. Untuk penyemprot air statis biasanya terintegrasi dengan sensor asap yang merupakan standar internasional dan biasanya menggunakan sprinkler. Untuk penyemprotan air dinamis, arah air dapat dikendalikan oleh sistem.

Pemantauan kebakaran via internet menjadi satu hal yang dapat menggantikan peran alarm yang hanya terbatas jangkauan informasinya pada lokasi kejadian, sedangkan dengan internet pemberitahuan dapat diberikan kepada pengguna ataupun suatu komunitas. Seperti pada penelitian [9] [10], penelitian ini pun memanfaatkan internet dan smartphone untuk pemantau kebakaran.

\section{Internet of Things}

Internet of Things (IoT) adalah suatu konsep komunikasi data melalui jaringan internet yang memiliki kemampuan untuk koneksi antar obyek seperti sensor, aktuator atau pengendali [13]. IoT memilik kemampuan untuk pengendalian otomatis jarak jauh. Banyak penelitian di berbagai bidang dengan menggunakan IoT ini seperti monitoring tanah longsor [14], penelitian di bidang irigasi sawah [15], penelitian untuk peternakan yaitu memonitoring suhu, kelembaban dan gas ammonia [16], dan Sistem kendali jarak jauh pada rumah pintar [17][18]

\section{METODE}

Metode penelitian yang dilakukan adalah metode penelitian eksperimental. Dalam penelitian ini dibuat purwarupa dari sistem pendeteksian dini kebakaran dan pemadamannya secara otomatis dengan penerapan konsep Internet of Things.

\section{Model Sistem}

Model sistem adalah berbentuk ruangan seperti pada Gambar 1. Sensor asap, sensor api dan sensor kamera diletakan pada atas ruangan. Sensor api dan kamera diletak dalam sebuah batang yang dapat digerakkan berputar menggunakan motor servo. Arduino digunakan untuk akuisisi data dari sensor ataupun memberikan sinyal perintal untuk sensor kamera, motor servo dan pompa air. Ethernet shield digunakan untuk komunikasi data dari Arduino ke HP atau sebaliknya.

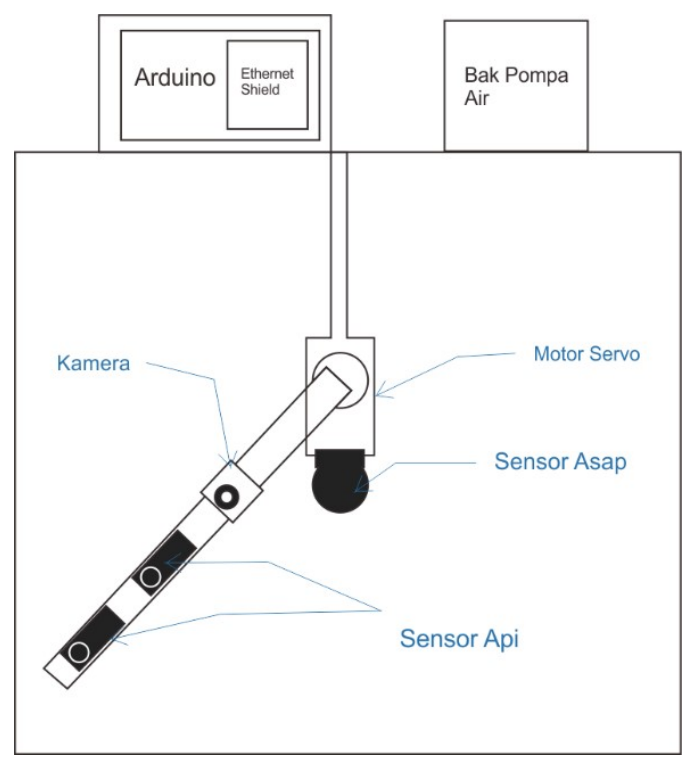

Gambar 1. Maket Sistem Pendeteksi Dini Kebakaran

Sensor api yang digunakan dua buah bertujuan untuk membedakan posisi titik api apakah titik api jauh atau titik api dekat terhadap titik tengah motor servo sebagai pusat pergerakan batang sensor. Bila titik api lebih dekat ke sensor 1 artinya titik api dekat. Posisi titik api dapat dilihat pada Gambar 2. Oleh karena motor servo diberi kecepatan konstan, maka dibuatlah posisi ruangan menjadi 100 titik, dari posisi 0 sampai 99. 


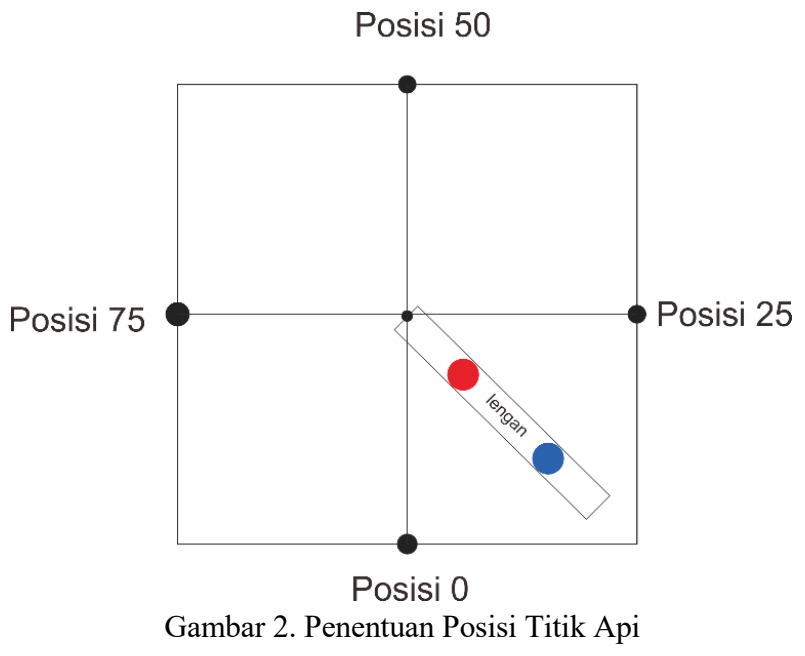

\section{Perancangan Sistem}

Rancangan sistem dapat dilihat pada Gambar 3. Terlihat dari Gambar 3 tersebut sistem terbagi dua kelompok yaitu kelompok sistem akuisi data dan kelompok komunikasi data.

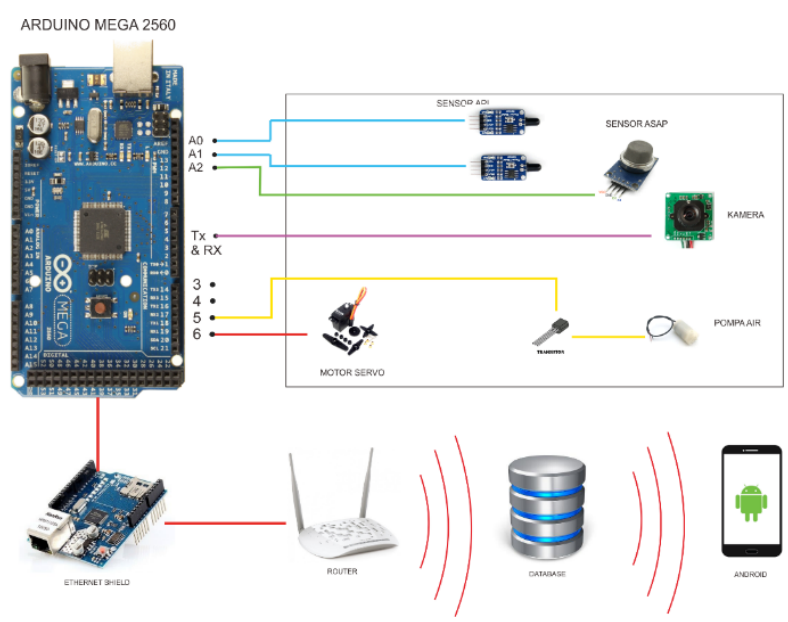

Gambar 3. Sistem Pendeteksian Dini Kebakran Berbasis IoT

Bagian kelompok pertama yaitu perancangan akuisi data. Pada perancangan sistem akuisi data dan pemrograman ini dibahas bagaimana data dari sensor, kamera, motor servo serta pompa diolah dan diatur oleh mikrokontroler Arduino Mega.

\section{Sensor Asap MQ-2}

Sensor asap MQ-2 dapat dilihat pada Gambar 4. Besarnya tegangan yang menjadi output dari sensor bergantung pada tingkat kepekatan sensor terhadap gas yang ada disekitarnya. Pada sistem ini ketika sensor menerima adanya tanda asap, sensor akan mengirimkan sinyal tegangan ke arduino sebagai tanda adanya asap. Sensor asap akan menghasilkan pulsa positif sebesar 0.25-1.20 volt dan sensor akan berada pada posisi HIGH. Tegangan ini akan dikonversi ke arduino dengan menggunakan ADC (Analog Digital Converter) dimana akan menjadi 1024 level data $\left(2^{10}=1024\right)$ karena arduino menerima data 10 bit. Artinya jika nilai data 0 maka akan merepresentasikan tegangan
0 Volt, dan nilai 1023 akan merepresentasikan tegangan 5 Volt. Jika tegangan 5 Volt dikonversi ke data digital 10 bit, maka akan menjadi :

Setiap level data digital $=\frac{5 \text { Volt }}{1023}=0.004887585 \mathrm{~V}$.

Jadi apabila output MQ-2 sebesar $0,25 \mathrm{~V}$, maka levelnya = $0,25 / 0,004887585=51$. Untuk $1,3 \mathrm{~V}$, levelnya $=245$.

Oleh karena itu, Arduino akan menganggap sistem terdapat asap apabila Arduino menghitung nilai sensor asap antara 51-245.

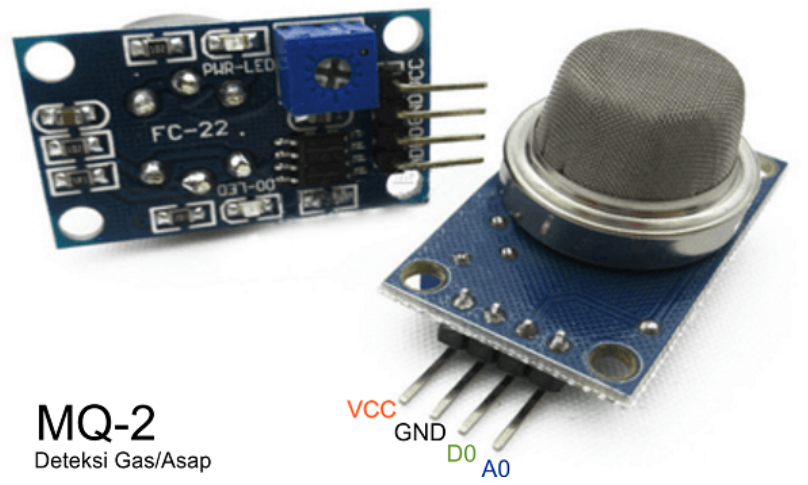

Gambar 4. Sensor Asap MQ-2 [19]

\section{Motor Servo}

Motor Servo akan bergerak untuk dua kondisi. Pertama jika kondisi terdeteksi asap, dan kedua ketika adanya perintah dari android (operator), untuk perintah android terjadi ketika arduino membaca string/teks yang ada pada database yang memicu servo untuk bergerak. Servo bergerak dengan kecepatan tetap. Ketika dalam masa rotasi mencari titik api, servo akan terus bergerak, sampai sensor api mendeteksi ada titik api. Ketika ada titik api yang terdeteksi oleh sensor api, maka servo akan berhenti.

\section{Sensor Api}

Sensor Api yang digunakan pada sistem ini ada 2, berguna untuk mendeteksi titik api jauh dan dekat. Sensor api akan mulai mendeteksi inframerah bersamaan dengan jalannya motor servo. Inframerah yang diterima oleh sensor api akan dikonversi menjadi digital di Arduino. Jika sensor api mendeteksi api maka nilai yang akan dikirimkan lebih kecil dibandingkan ketika tidak ada api. Nilai tegangan yang diperoleh oleh masing-masing sensor akan dibandingkan. Contoh kasus pada Gambar 5 titik api berada di dekat sensor api jauh, sensor api jauh mendeteksi dengan nilai yang kecil, dan sensor api dekat mendeteksi nilai dengan nilai yang lebih besar.

Tinjau Gambar 6, asusmi jika phototransistor pada sensor api jauh mendeteksi api dan memberikan tegangan 4 Volt dan tegangan trimpot adalah 5 Volt, selisihnya adalah 1 Volt maka tegangan ini menjadi input ke pin analog arduino dengan diubah ke digital. Dan jika pada photodioda pada sensor api dekat mendeteksi tegangan 2 Volt dengan nilai tegangan trimpot 5 Volt, maka selisihnya adalah 3 Volt yang akan menjadi input ke Arduino. 


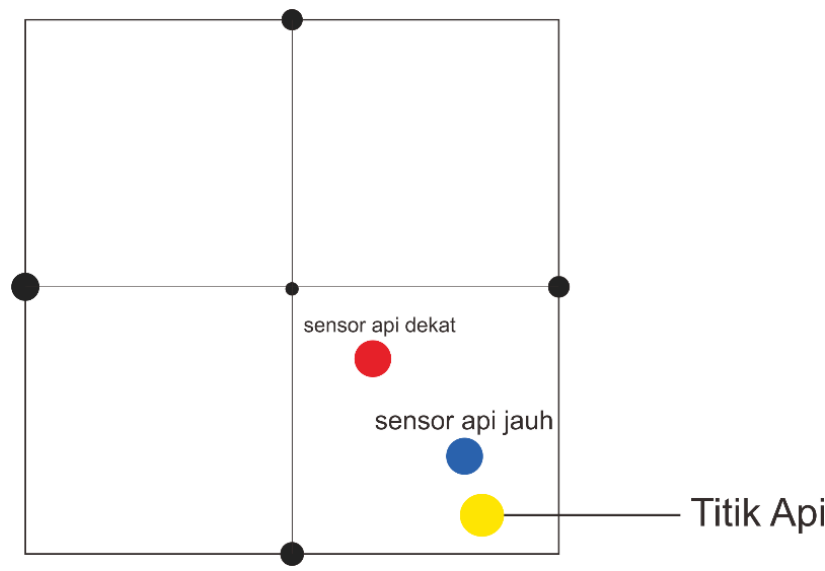

Gambar 5. Contoh Perhitungan Posisi Titik Api

Level nilai digital untuk $1 \mathrm{~V}=204$, dan level untuk $3 \mathrm{~V}=613$. Artinya, Arduino akan membandingkan bahwa posisi titik api adalah api jauh karena level api jauh $<$ api dekat.

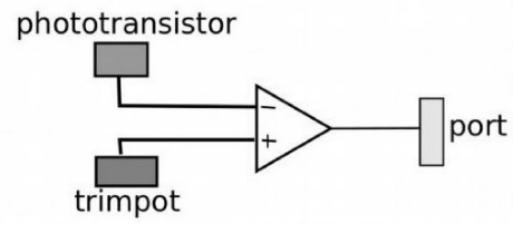

Gambar 6. Rangkaian Dasar Sensor Api

\section{Sensor Kamera}

Sensor kamera pada purwarupa ini dikoneksikan dengan sebuah ethernet shield menggunakan serial komunikasi UART (Universal Asynchronous Receiver Transmitter), dimana komunikasi data antara kamera dan aruduino terjadi pada pin $\mathrm{Tx}$ dan Rx. Kamera menerima logika untuk mengambil gambar ketika servo berhenti melalui kaki Rx yang tersambung ke pin Tx pada arduino. Dan setelah kamera mengambil gambar, data gambar akan dikirimkan melalui kaki Tx ke pin $\mathrm{Rx}$ diarduino untuk selanjutnya disimpan pada Sd Card di Ethernet Shield. Ethernet Shield memiliki slot SD Card untuk media penyimpanan gambar dari kamera. Proses ini dimulai dengan pengecekan client pada ethernet shield terkoneksi ke internet, serta pengecekan $S d$ Card yang ada pada ethernet shield. setl Kamera pada prototipe ini akan mulai mulakukan pengambilan gambar pada titik api bersamaan dengan berhentinya motor servo. Pada pengambilan gambar yang dilakukan oleh kamera ini dimulai dengan pengecekan kamera dan versi kamera. Setelah dilakukan pengecekan, akan ditentukan resolusi gambar yang akan ditangkap oleh kamera, dalam prototipe ini resolusi gambar 320 x 240 pixel. Setelah dilakukan pemilihan resolusi gambar, kamera akan melakukan pengambilan gambar, Setelah data gambar ditangkap oleh kamera, maka akan disimpan pada $S d$ Card yang ada pada Ethernet Shield dengan nama "image" serta dalam format “.jpg”. setelah gambar tersimpan pada $S d$ Card yang ada pada ethernet shield, maka gambar ini akan diakses oleh Android untuk ditampilkan di aplikasi.

\section{Pompa Air}

Pada Prototipe ini pompa akan bekerja dalam 2 kondisi. Pertama ketika ada input operator untuk menghidupkan pompa. Kedua ketika tidak ada respon operator pada sistem dan pompa hidup otomatis. Kekuatan pompa akan tergantung pada posisi titik api yang telah dideteksi oleh sensor api ketika pompa hidup. Sensor api akan tetap melakukan pendeteksian titik api sampai api padam. Jika api sudah padam, maka sensor api memberikan output agar pompa berhenti.

\section{Perancangan Program Sistem Akuisi Data}

Dalam perancangan program, terdapat dua kelompok pemrograman. Bagian kelompok pertama adalah program sistem akuisisi data. Pemprograman untuk Arduino ini menggunakan bahassa C. Bagian kelompok kedua adalah perancangan sistem komunikasi data. Terdiri dari dua jenis pemprograman yaitu pemprograman PHP dan Pemprograman Android.

Gambar 7 memperlihatkan diagram alir program sistem akuisisi data. Dalam program ini tidak saja mengambil dan mengolah data-data dari sensor seperti sensor asap, api, dan kamera, tetapi juga mengatur sinyal keluaran untuk aktuator seperti motor servo penggerak sensor api dan kamera serta mengatur semburan air dari pompa air.

Program Arduino inipun mengatur data yang disimpan pada database untuk ditransfer ke android ataupun mengolah data dari database yang diinputkan oleh android ke database.

\section{Perancangan Program PHP}

Untuk mengirim dan menerima data dari database ke arduino dan android dibuat dengan pemprograman PHP. Beberapa program PHP yang digunakan, yaitu program untuk menerima data dari Arduino dan mengirimkannya ke database, menngambil data dari database untuk Arduino, mengambil data dari database untuk Android, dan program PHP untuk mengirimkan data ke database melalui empat tombol perintah pada Android.

\section{Perancangan Program Android}

Pemprograman Android menggunakan bahasa pemprograman Java. Diagram alir untuk pemprogramannya dapat dilihat pada Gambar 8 .

Pada pemrograman ini terdapat tiga skenario. Pertama, Android mendapat pemberitahuan adanya api dari Arduino dan kondisi ruangan terlihat dari foto yang dikirim kamera. Respon Android adalah memadamkan api atau tidak bergantung dari keputusan operator yang menyatakan api atau bukan api. Kedua, operator memerintahkan andoid dengan menekan tombol "scan" yang diterima oleh Arduino untuk memutar servo sensor api. Ketiga, dalam hal android terlambat merespon Arduino dalam kondisi adanya api, maka dalam progam Arduino terdapat suatu nilai waktu delay yang memutuskan sistem untuk memadamkan api dengan menghidupkan pompa air. 

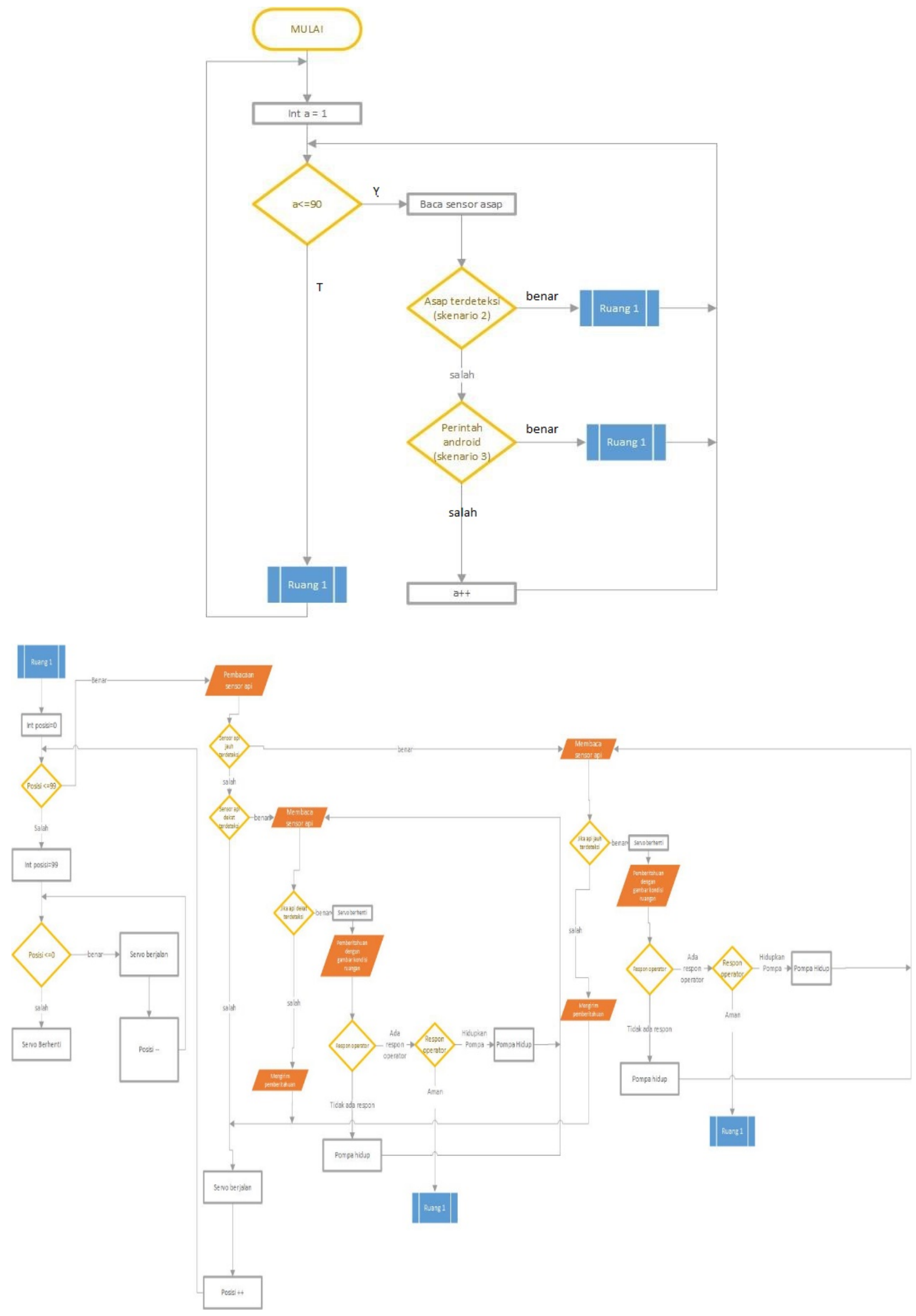

Gambar 7. Diagram Alir Sistem Akuisi Data 

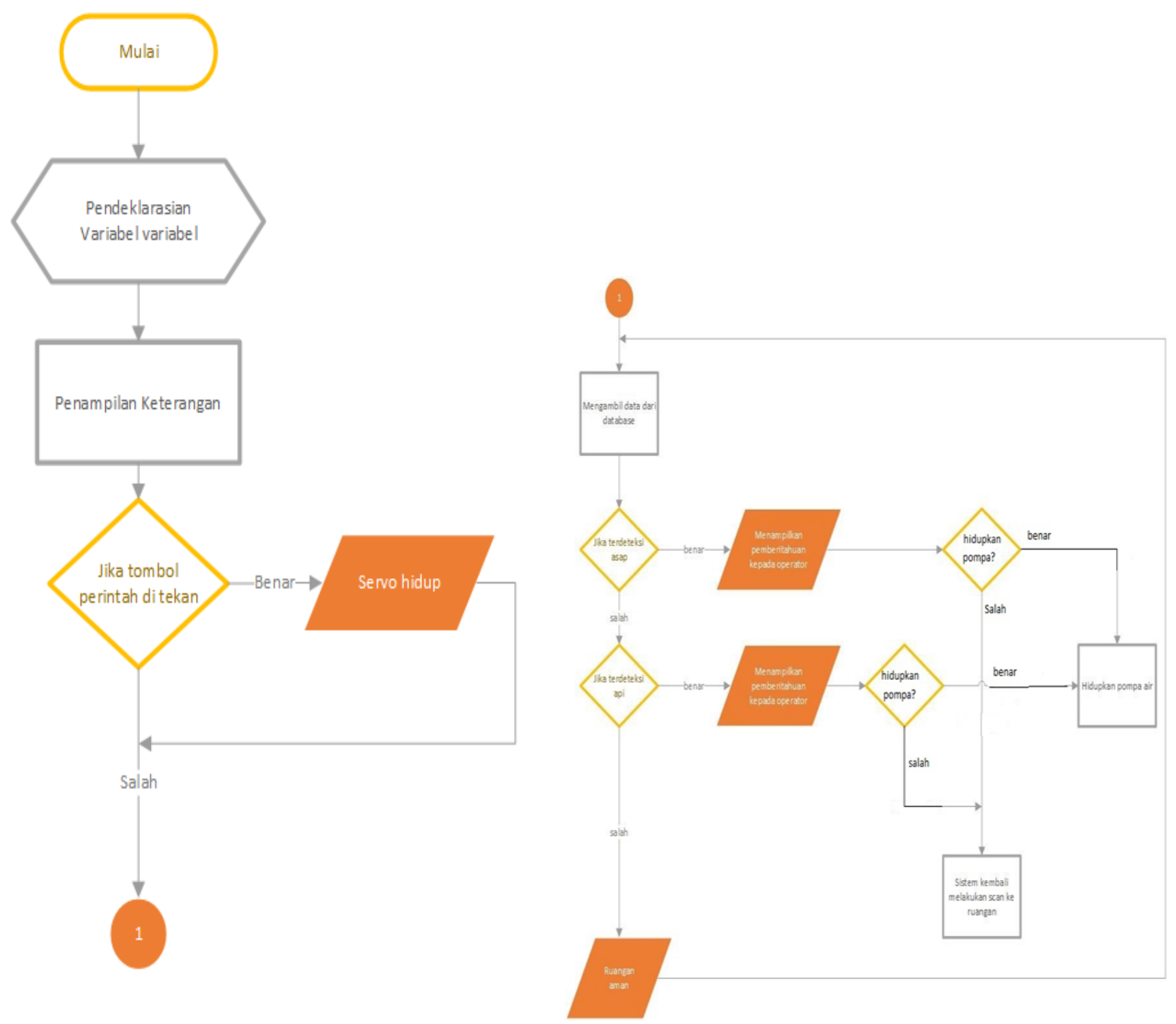

Gambar 8 Diagram Alir Program Android

\section{HASIL DAN PEMBAHASAN}

\section{Implementasi Perangkat Keras}

Sistem Pendeteksian dini kebakaran dan pemadaman berbasis IoT telah dibuat dalam bentuk purwarupa seperti dalam Gambar 9.

\section{Pengujian Kamera}

Pada tahap ini akan dilakukan pengujian pengambilan gambar beberapa titik api yang dikondisikan pada ruangan. objek yang digunakan sebagai sumber api adalah lilin. Kondisi peletakan lilin pada percobaan ini dapat dilihat pada Gambar 10. Pada pengujian ini terdapat 4 posisi titik api yang akan di ujikan yaitu jauh dari sensor api 1 (y), di dekat sensor api 1(x), diantara sensor api 1 dan 2 (n), dan di belakang sensor api 2 (m).

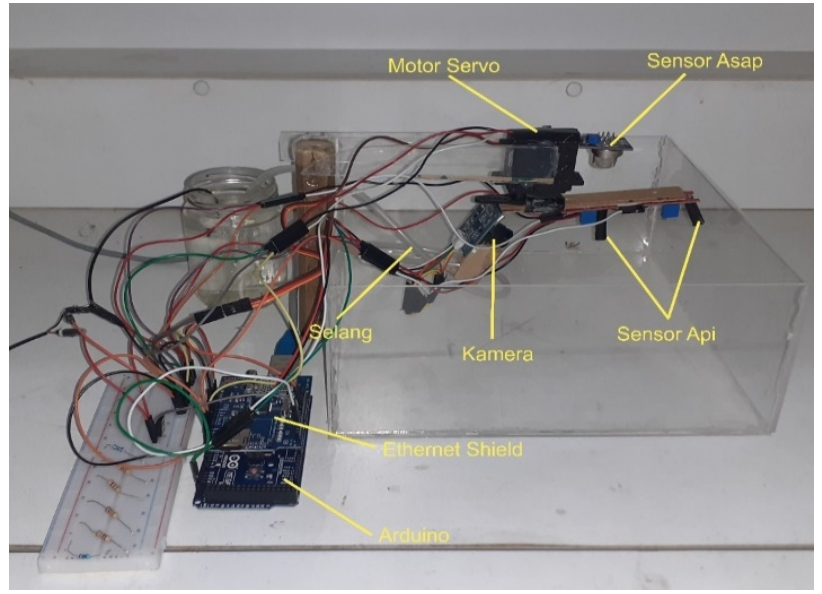

Gambar 9. Purwarupa Sistem Pendeteksi Dini Kebakaran 
Tabel 1. Hasil Pengujian Kamera

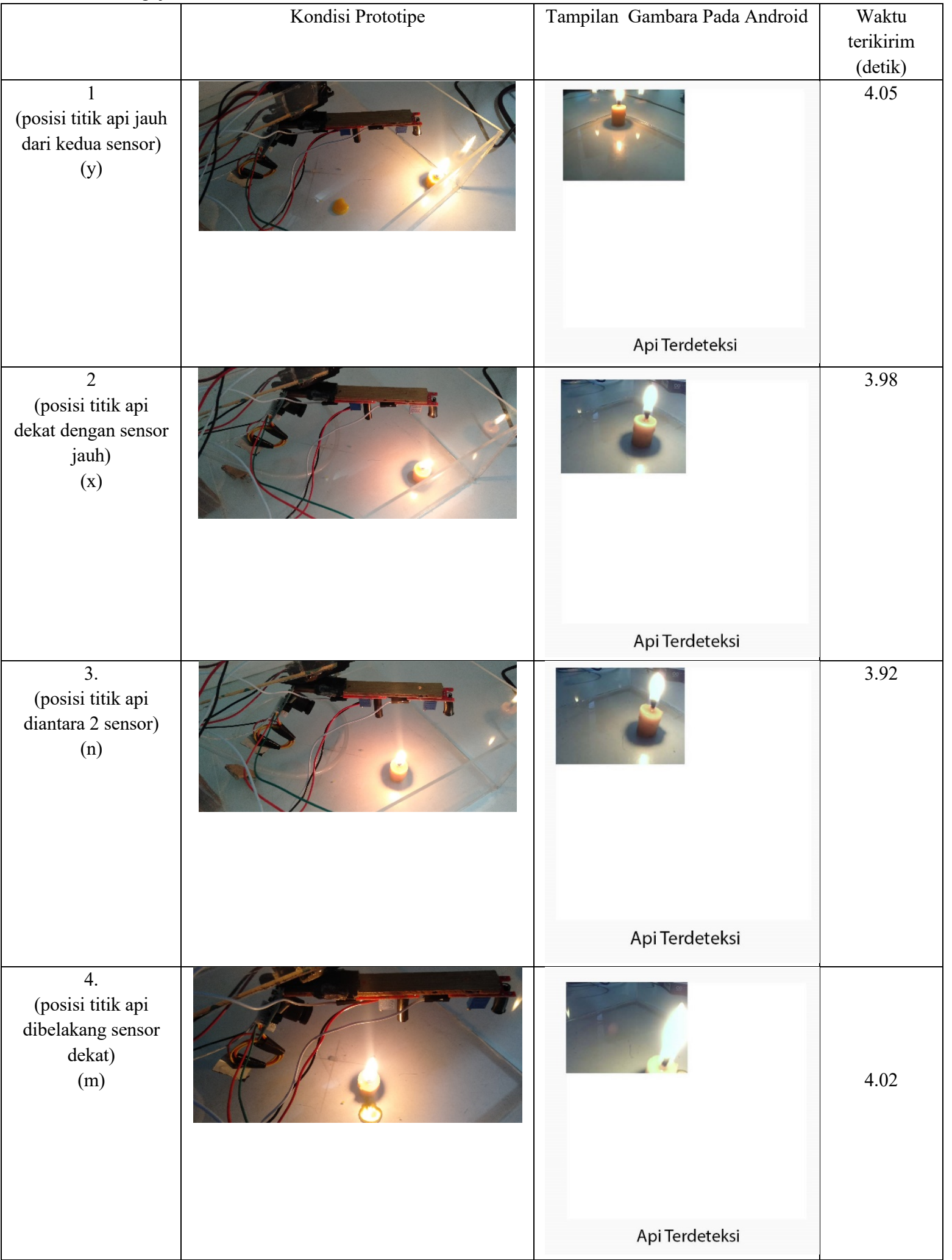


Posisi 50

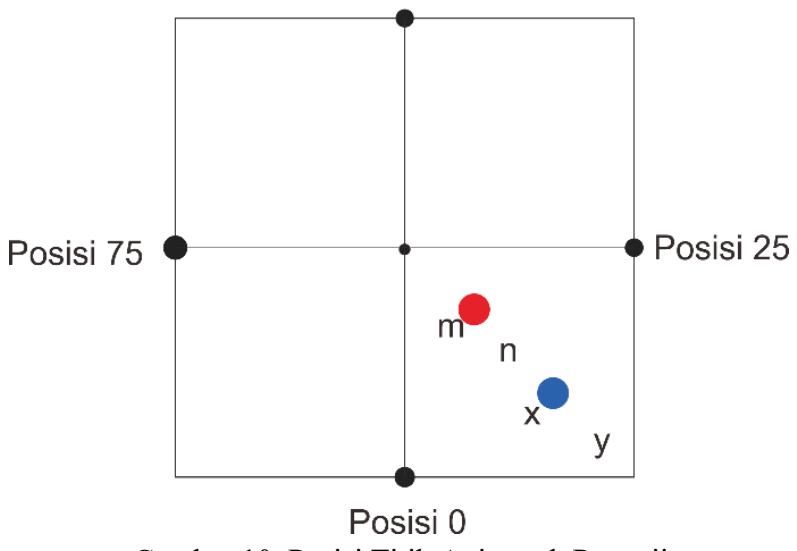

Gambar 10. Posisi Titik Api untuk Pengujian

Hasil pengujian kamera dapat dilihat pada Tabel 1. Terlihat screenshots tampilan webview dari aplikasi android yang menampilkan foto kondisi ruangan ketika terdeteksi titik api. Waktu yang dihitung pada pengujian ini terhitung dari ketika servo berhenti dan kamera langsung memotret kondisi ruangan.Rata-rata yang di yang butuhkan android untuk menampilkan gambar yang disimpan pada sd card ethernet shield adalah 4.105 detik. Dapat dikatakan kamera dapat berfungsi.

\section{Pengujian False Alarm}

Dalam pengujian ini sinyal dari sensor api dikelompokan dalam sinyal api yang sesungguhnya dan sinyal api yang bukan sesungguhnya. False alarm merupaakan sinyal api yang bukan sesungguhnya. Kedua hasil pengujian terlihat pada Tabel 2 dan Tabel 3. Untuk pengujian ini api lilin dianggap sebagai api sesungguhnya sedangkan api obat nyamuk sebagai false alarm.

Hasil pengujian sinyal api yang sesungguhnya terlihat bahwa sistem mampu mendeteksi sinyal api dan operator dapat memerintahkan sistem untuk memadamkan api. Tampilan HP android dapat dilihat pada Gambar 11. Tampilan Gambar 11 tersebut terlihat ketika kamera aktif mengambil gambar situasi ruangan. Selanjutnya adalah menunggu respon dari operator apakah menghidupka pompa air atau tidak.

Tabel 3 memperlihatkan bahwa asap terdeteksi dan sensor api aktif sehingga kamera juga aktif untuk mengambil gambar situasi ruangan. Dalam hal ini, operator berperan besar untuk menentukan bahwa sinyal tersebut adalah false alarm,

Hasil pengujian ini memperlihatkan bahwa sistem pendeteksian dini berbasis IoT dapat mencegah terjadinya false alarm.

\section{Pembahasan}

Beberapa penelitian yang telah dilakukan memperlihatkan bahwa penambahan sensor untuk pendeteksian dini kebakaran selain sensor asap dapat menambah kemampuan pendeteksian dini lebih baik.
Tabel 2. Hasil Pengujian Sinyal Api yang Sesungguhnya

\begin{tabular}{|c|c|c|}
\hline Posisi & $\begin{array}{l}\text { Kondisi ruangan ketika } \\
\text { pompa hidup }\end{array}$ & Waktu ${ }^{\#}$ detik) \\
\hline $\begin{array}{c}1 \\
\text { (posisi } \\
\text { titik api } \\
\text { jauh dari } \\
\text { kedua } \\
\text { sensor) } \\
\text { (y) }\end{array}$ & & 3.05 \\
\hline $\begin{array}{c}2 \\
\text { (posisi } \\
\text { titik api } \\
\text { dekat } \\
\text { dengan } \\
\text { sensor } \\
\text { jauh) } \\
\text { (x) }\end{array}$ & & 2.98 \\
\hline $\begin{array}{c}3 . \\
\text { (posisi } \\
\text { titik api } \\
\text { diantara } 2 \\
\text { sensor) } \\
\text { (n) }\end{array}$ & & 3.02 \\
\hline $\begin{array}{c}4 . \\
\text { (posisi } \\
\text { titik api } \\
\text { dibelakan } \\
\text { g sensor } \\
\text { dekat) } \\
\text { (m) }\end{array}$ & & 3.02 \\
\hline
\end{tabular}

(Keterangan: Waktu\# adalah waktu tombol Hidupkan Pompa ditekan sampai pompa hidup)

Penelitian [7] menambahkan sensor api untuk mengetahui lokasi api. Hasil [20] memperlihatkan bahwa bila detektor asap aktif lebih dari 2 maka sinyal alarm diaktifkan. Untuk memperlihatkan bahwa kebakaran itu benar terjadi bahkan sistem pendeteksian dini kebakaran menambahkan kamera seperti pada penelitian [8] dan [21]. Hasil-hasil penelitian ini memperlihatkan bahwa semakin banyak jumlah sensor akan menambah kemampuan sistem.

Penelitian [11] memperlihatkan penggunaan tiga macam sensor yaitu sensor asap, sensor temperatur dan sensor api. Hasilnya memperlihatkan perkembangan yang berarti untuk pemakaian banyak sensor dibandingkan dengan sistem pendeteksian kebakaran yang standar. 
Tabel 3. Pengujian Sinyal Api sebagai False Alarm

\begin{tabular}{|c|c|c|}
\hline Posisi & Tampilan Android & Waktu $^{*}($ detik$)$ \\
\hline $\begin{array}{c}1 \\
\text { (posisi } \\
\text { di dekat } \\
\text { sensor } \\
\text { 1) }\end{array}$ & Asap Terdeteksi & 更 \\
\hline $\begin{array}{c}2 \\
\text { (posisi } \\
\text { diantara } \\
2 \\
\text { sensor) }\end{array}$ & Asap Terdeteksi & 更 \\
\hline $\begin{array}{c}3 \\
\text { (posisi } \\
\text { di dekat } \\
\text { sensor } \\
\text { 2) }\end{array}$ & Asap Terdeteksi & 3.87 \\
\hline
\end{tabular}

Seperti dinyatakan dalam pendahuluan bahwa false alarm dapat sangat merugikan. Sinyal pemberitahuan secara otomatis tanpa adanya verifikasi dari manusia bahwa api yang terdeteksi adalah benar sumber kebakaran dapat dicegah dengan pengiriman informasi kebakaran ini ke beberapa pihak terkait seperti pemilik rumah, pemilik apartemen, supervisor, dan badan pemadam kebakaran [9] [10] [20] [21 ]. Hal ini memperlihatkan bahwa walaupun sistem pendeteksian dini kebakaran dibuat otomatis tetapi peranan manusia untuk mengambil keputusan tetap diperlukan.

Implementasi purwarupa ini dalam ruangan sesungguhnya memerlukan banyak penyesuaian. Beberapa hal yang harus disesuaikan adalah sebagai berikut. Pertama, letak dan ukuran sensor dan aktuator dalam ruangan. Kedua, berapa ukuran minimal kadar asap atau intensitas cahaya api yang dipancarkan dalam ruangan.

Untuk ukuran sensor asap dan sensor api masih tetap sama dan dapat diletakkan dibagian atas ruangan dengan memperhatikan estetika ruangan, sedangkan untuk aktuator pompa air dan selang penyemprot air dapat digantikan dengan sprinkler dinamis yang dapat berputar pada arah tertentu.

Untuk ukuran minimal kadar asap sensor asap dan intensitas cahaya sensor api pada dasarnya dapat disesuaikan dengan spesifikasi sensor tersebut. Untuk ruangan yang sangat besar seperti ruang kelas dapat diatasi dengan distribusi sensor pada luas bidang tertentu.

(Keterangan: Waktu* adalah Waktu yang dibutuhkan sistem untuk kembali scaning ruangan ketika tombol aman ditekan pada HP android)

\section{KESIMPULAN}

Penelitian ini telah berhasil membangun purwarupa dari sistem pendeteksi dini dan pemadaman kebakaran otomatis berbasis Internet of Things dengan penambahan kemampuan untuk membedakan sinyal api false alarm.

\section{UCAPAN TERIMAKASIH}

Penulis mengucapkan terimakasih kepada Fakultas Teknik Universitas Andalas atas dukungannya dalam dana penelitian dengan Kontrak Perjanjian No. 094/UN.16.09.D/PL/2019. 


\section{DAFTAR PUSTAKA}

[1] H. Permana and IH. Susilowati." Evaluation of Reliability Values of the Building Safety System against Fire Hazards in the X Government Office Building in Jakarta". in International Conference of Occupational Health and Safety (ICOHS-2017), KnE Life Sciences, pages 607-615. DOI: 10.18502/kls.v4i5.2590. 2018.

[2] S.G Badger, "Large-Loss Fires in the United States 2016," NFPA Research, Quincy, MA, November 2017.

[3] C. Grant, A. Harnins, N. Bryner, A. Jones, and G, Koepke. "Research Roadmap for Smart Fire Fighting". Summary Report, NIST Special Publication 1191. Available on www.nfpa.org/SmartFireFighting, DOI: http://dx.doi.org/10.6028/NIST.SP.1191. May 2015.

[4] R. Chagger and D. Smith, "The Causes of false fire alarms in buildings", Briefing Paper, Report Number BC2982, BRE Global Ltd 2014, [online], available on http://www.bre.co.uk, [diakses: 10 Nopember 2019].

[5] M. J. Charter, Jr., "False Alarms Activity in The U.S. 2012", NFPA Fire Analysis and Research Division, Quincy, MA,[online], Availble on http://www.nfpa.org, \{diakses: 13 Nopember 2019], Desember 2013

[6] S. Feslag. "False alarm ratio of fire detection and fire alarm systems in Germany - A meta analysis," Fire Safety Journal, Vol 79, pp. 119-126, 2016

[7] D. Astharini, S. Rahmatia, T, Apridinata, dan R.P. Batubara, "Pengembangan Sistem Pendeteksi Lokasi Titik Api dalam Ruangan Terbatas," Jurnal Al-Azhar Indonesia Seri Sains dan Teknologi, Vol 2 no. 2, hal. 91-95, September 2013

[8] X. Wu, X. Lu and H. Leung, "A Video Based Fire Smoke Detection Using Robust AdaBoost”, Sensors, 18, 3780,doi: 10.3390/s18113780, 2018

[9] DU Chunquan and ZHU Shunbing. " Research on urban public safety emergency management early warning system based on technologies for the internet of things". Procedia Engineering, Vol. 45, pp. 748-754. 2012.

[10] K. Yin and J. Jiang. "An Application Of Internet Of Things In The Field Of Urban Building Fire Safety," Int. J. of Safety and Security Eng., Vol. 4, No. 2, pp.135-142, 2014.

[11] R. Sowah, A. R. Ofoli, S. Krakani, and S. Fiawoo, "Hardware Design and Web-based Communication Modules of a Real-time Multi-Sensor Fire Detection and Notification System using Fuzzy Logic," 2014 IEEE Industry Application Society Annual Meeting, DOI: 10.1109/IAS.2014.6978415

[12] J. A. Luis, J. G. Galán and J. A. Espigado, "Low Power Wireless Smoke Alarm System in Home Fires," Sensors, Vol. 15, pp. 20717-20729, DOI:10.3390/s150820717, 2015

[13] J. A. Stankovic, "Research Directions for the Internet of Things," in IEEE Internet of Things Journal, vol. 1, no. 1, pp. 3-9, Feb. 2014, doi: 10.1109/JIOT.2014.2312291

[14] R.W. Putra dan H. Suryamen, "Sistem Monitoring Tanah Longsor Berbasis Internet of Things dan Geographic Information System," Journal of Informatiom Technology and Computer Engineering (JITCE), vol. 03 no. 02, 70-79, 2019

[15] T. Husna, D.I Putra, dan W. Kasoep, "Sistem Pengatur Irigasi Sawah menggunakan metode Irigasi Alternate Wetting dan Drying Berbasis Teknologi Internet of Things, Journal of Informatiom Technology and Computer Engineering (JITCE), vol. 02 no. 02, 92-100, 2018

[16] A. Tiffani, D.I Putra dan T. Erlina, "Sistem Monitoring Suhu, Kelembaban dan Gas Amonia pada Kandang Sapi
Perah Berbasis Teknologi Internet of Things (IoT), J Journal of Informatiom Technology and Computer Engineering (JITCE), vol. 01 no. 01, 33-39, 2017

[17] M. Muharam, M. Latif dan M. Saputra, "Sistem Kendali Jarak Jauh Berbasis Web untuk Sistem Rumah Pintar," JNTE, vol. 7, no. 3, 203-208, November 2018

[18] D. Yendri dan R.E. Putri, "Sistem Pengontrolan dan Keamanan Rumah Pintar (Smart Home) Berbasis Android," Journal of Informatiom Technology and Computer Engineering (JITCE), vol. 02 no. 01, 1-6, 2018

[19] lastminuteengineers.com, "In-Depth: How MQ2 Gas/Smoke Sensor Works? \& Interface it with Arduino." [Online]. Available: https://lastminuteengineers.com/mq2gas-senser-arduino-tutorial/. [Diakses: 28-Oct-2019].

[20] Y. Chen. "Reliability analysis of a fire alarm system," Procedia Engineering, Vol. 24, pp. 731-736, 2011

[21] H. Wu, D. Wu and J. Zhao. "An intelligent fire detection approach through cameras based on computer vision methods," Process Safety and Environmental Protection, Vol. 127, pp. 245-256, 2019

\section{BIOGRAPHY PENULIS}

Mumuh Muharam menjalani pendidikan S1 di jurusan Teknik Fisika ITB dan lulus pada tahun 1993, sedangkan pendidika S2 pada Program Pasca sarjan Teknik Elektro ITB dan lulus 2000. Sejak tahun 1998 sampai sekarang bekerja sebagai Dosen di jurusan Teknik Elektro Fakultas Teknik Unand. Adapun bidang penelitian yang ditekuni adalah penelitian di bidang Teknik kendali baik yang bersifat teoritis ataupun aplikasi berbasiskan teknologi komputer atau internet. Email: mumuh@eng.unand.ac.id

Melda Latif menamatkan pendidikan S1 di bidang Teknik elektro pada Universitas Sumatra Utara (USU) pada 1994 dan lulus pada jenjang pendidikan S2 di program Pascasarjana Teknik Elektro pada 2006. Sejak tahun 1998 sampai sekarang bekerja sebagai Dosen di jurusan Teknik Elektro Fakultas Teknik Unand. Adapun bidang penelitian yang ditekuni adalah penelitian di bidang konversi energi seperti penelitian pada energi terbarukan dan penelitian yang berkaitan dengan teknologi pengendalian mesin-mesin listrik. Email: melda latif@eng.unand.ac.id

Baharuddin adalah staf pengajar Jurusan Teknik Elektro Fakultas Teknik Universitas Andalas Padang. Lulus Program Sarjana pada tahun 1993 pada Bidang Teknik Telekomunikasi dan Elektronika Jurusan Teknik Elektro Fakultas Teknik Universitas Hasanuddin. Pada tahun 2005 menyelesaikan studi program magister bidang Telekomunikasi Multimedia di ITS Surabaya. Email: baharuddin@eng.unand.ac.id

Ibnum Richaflor menjalani pendidikan S1 di jurusan Teknik Elektro Fakultas Tekni Unand. Penelitian yang ditekuni adalah pengendalian dan penerapan teknologi yang berbasiskan internet.Email: richafloribnum@gmail.com 